\title{
Anticausatives compete but do not differ in meaning: a French case study
}

\author{
Martin, Fabienne \& Schäfer, Florian
}

Universität Stuttgart

fabienne.martin@ling.uni-stuttgart, florian@ifla.uni-stuttgart.de

\section{Introduction}

In French as in many other Romance and Germanic languages, verbs undergoing the causative/anticausative alternation divide into two morphological and three distributional classes. With verbs of class $\mathrm{A}$, the anticausative (AC) is morphologically unmarked ( $\varnothing$-ACs), cf. (1). With verbs of class $\mathrm{B}$, the $\mathrm{AC}$ is marked with the reflexive clitic se (se-ACs), cf. (2). ACs of class $\mathrm{C}$ allow both markings (Ø/se-ACs) allow both markings, cf. (3).
a. $\quad$ Le poulet cuit.
The chicken $\varnothing$ is cooking.
a. $\quad *$ L'image agrandit.
The picture $\varnothing$ is widening.
a. Le vase casse.
The vase $\varnothing$ is breaking.

b. ??Le poulet se cuit. the chicken SE is cooking.

b. L'image s'agrandit.

The picture SE is widening.

b. Le vase se casse.

The vase SE is breaking.

Several authors have proposed that the presence vs. absence of the reflexive clitic goes along with differences in meaning, see e.g. Labelle 1992, Doron \& Labelle 2011, Labelle \& Doron 2010, according to which $s e$-ACs express externally caused events while $\varnothing$-ACs express internally caused events (claim 1) and se-ACs focus on the achievement of a result state while $\varnothing$-ACs focus on a process (claim 2). To derive these alleged differences in meaning, fundamentally different syntactic structures have been proposed for se-ACs and $\varnothing$-ACs: Labelle 1992 argues that $s e$-ACs are unaccusative while $\varnothing$-ACs are unergative, whereas Doron \& Labelle 2011 and Labelle \& Doron 2010 (henceforth DL) propose that seACs and $\varnothing$-ACs are both unaccusative but differ substantially in their event decomposition and the position where the lexical root is merged in the structure.

The goal of this paper is to show that most of the meaning differences proposed to hold between se-ACs and $\varnothing$-ACs are either not existent or idiosyncratic/verb-specific. In particular, they cannot be generalized to the presence/absence of morphological marking. This makes a structural explanation of these meaning differences unfeasible: the presence vs. absence of se cannot be associated with syntactic differences driving meaning differences. To the extent that meaning aspects can be robustly associated with either marked or unmarked ACs, we argue that this holds only for verbs of class $C$ (optional marking; cf. also Legendre \& Smolensky 2009). We derive these within a pragmatic account: with verbs of class C (i.e. if a choice is possible), a pragmatic reasoning on the possible interpretations of the string [DP se V] (AC or also semantically reflexive) leads the speaker to prefer one version over the other. Note that we do not deny any syntactic differences between $\varnothing$-ACs and se-ACs: the presence of se suggests a syntactic extra- 
layer on top of vP, a middle or expletive Voice (Doron 2003, Alexiadou et al. 2006, Schäfer 2008). The presence of this expletive Voice projection triggers (morpho-)syntactic differences (e.g. auxiliary selection) but does not add any semantics. Semantically reflexive verbs and reflexively marked anticausatives, on the other hand, differ syntactically and semantically, but this difference is not visible at the surface. The relevant (underlying) structures are given below:
I. Causative:
a. [voicep $D P_{\text {nom }}$ Voice $_{\text {active }}\left[\mathrm{vP} \vee\left[\right.\right.$ resultP $D P_{a c c}$ result]]]
b. $\quad \lambda \mathrm{x} \lambda \mathrm{y} \lambda \mathrm{e}$ (agent/causer(e, y) \& $\operatorname{CAUSE}(\mathrm{e}, \mathrm{s}) \&$ theme(s, y))
II. $\varnothing$-ACs: $\quad$ a. $\quad\left[\right.$ vP $\mathrm{V}\left[\right.$ resultP $D P_{\text {nom }}$ result $]$
b. $\quad \lambda y \lambda e(\operatorname{CAUSE}(e, s) \&$ theme $(s, y))$
c. $\quad \mathrm{DP}_{\text {Noм }}$ verb
III. se-ACs: $\quad$ a. $\quad$ [Voicep $s e$ Voice $_{\text {expletive }}\left[{ }_{\mathrm{vP}} \mathrm{V}\left[\right.\right.$ result $D P_{\text {nom }}$ result]]
b. $\quad \lambda \mathrm{y} \lambda \mathrm{e}(\operatorname{CAUSE}(\mathrm{e}, \mathrm{s}) \&$ theme $(\mathrm{s}, \mathrm{y}))$
c. $\quad \mathrm{DP}_{\text {Nom }}$ se-verb
IV. Reflexive: a. $\quad$ [voicep $\mathrm{DP}_{\text {nom }}$ Voice $_{\text {active }}[\mathrm{vP} \mathrm{V}$ [resultp $s e$ result]]]
b. $\quad \lambda \mathrm{x} \lambda \mathrm{y} \lambda \mathrm{e}(\operatorname{agent} / \mathrm{causer}(\mathrm{e}, \mathrm{y}) \& \operatorname{CAUSE}(\mathrm{e}, \mathrm{s}) \&$ theme(s, y) \& $(\mathrm{x}=\mathrm{y}))$
c. $\quad \mathrm{DP}_{\text {Nom }}$ se-verb

The paper is divided as follows. In section 2, we discuss the arguments presented in favour of Claim 1, show the empirical difficulties raised by these arguments and offer an alternative competition-driven account of the remaining data. In section 3, we present the arguments offered in favour of Claim 2, and show that they do not support the hypothesis of a systematic meaning difference between marked and unmarked anticausatives either.

\section{Alleged meaning difference 1: external vs. internal causation}

The distinction between internal and external causation was established by Levin \& Rappaport Hovav (1995) (who build on Smith 1970) to answer the question of when an intransitive verb has a transitive, causative counterpart. Externally caused VPs are defined as describing eventualities that are under control of some external cause that brings such an eventuality about (break, open). Internally caused VPs describe eventualities where some property inherent to the theme argument is 'responsible' for bringing about the eventuality (run, glow, blossom). The only test offered for internal vs. external causation is the (non-)existence of a causative counterpart, see. (4)-(5).
a. $\quad$ The door opened.
(externally caused)
b. John opened the door.
a. The flower blossomed.
b. $\quad *$ The gardener $/ *$ The sun blossomed the flower.
(internally caused)

A number of authors have argued that when a French verb is attested in both constructions (class C), the change of state (COS) is presented as internally caused when expressed by $\varnothing$-ACs and as externally caused when expressed by se-ACs (Claim 1, cf. Rothemberg 1974, Bernard 1971, Burston 1979, Labelle 1992, DL). Only in the former case the sole DP is assigned some responsibility for the coming about of the event. This should explain the contrast between (8a) and (8b). 

a. Il vit le mouchoir *(se) rougir.
(externally caused)
He saw the handkerchief (SE) redden.
b. Jeanne $(* \mathrm{se}) \quad$ rougit.
(internally caused)
Jeanne (SE) reddened/blushed.

This claim raises the following problems. First, if the presence/absence of morphology has semantic effects in class $\mathrm{C}$, the relevant semantic properties should also hold in class A and class B, respectively. This prediction holds at least in frameworks where the different morphology is directly correlated with different syntactic structures, which, in turn, are correlated with different event semantics, e.g. Labelle 1992, Labelle \& Doron 2010, Doron \& Labelle 2011 (it does not hold in the system proposed by Legendre \& Smolensky 2009). However, as acknowledged by Rothemberg 1974 herself and later emphasized by Zribi-Hertz 1987, there is no systematic correlation between the presence/absence of the reflexive morphology and the type of causation expressed: verbs of class B can express internally caused events, cf. (9), and verbs of class A can express externally caused events, cf. (10).
a. L'univers s'agrandit.
The universe SE is getting bigger.
a. Le bâtiment explose.
The building $\varnothing$ is exploding.

The second problem for Claim 1 is that only verbs of class $\mathrm{C}$ (incl. rougir) with animate subjects are problematic as se-AC, cp. (11a-b). Moreover, these examples with animate subjects are in fact problematic irrespectively of the type of causation involved; for instance, (12a-d), if acceptable, would express internally caused events, but (12e) would clearly denote an externally caused event. A related observation was already made by Zribi-Hertz 1987, see (12d-e), although she does not relate it to the difference between animate vs. inanimate subjects.

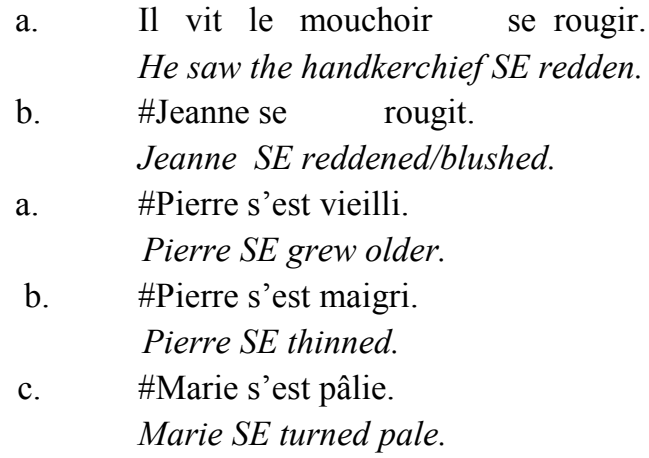

On the other hand, inanimate DPs are generally acceptable in the se-variant of class $\mathrm{C}$ verbs, irrespectively of internal/external causation (the examples in (13) are mostly taken from the internet and where checked with further informants): 
(13) a. Ses yeux se sont rougis à l'annonce de la victoire.

Her eyes $S E$ are reddened at the announcement of the victory.

b. Le vin est un produit qui vit, [...] se vieillit.

The wine is a product that lives, SE ages.

c. La laine est ressortie de la casserole vert foncé mais s'est pâlie.

The wool came out dark green from the pot but SE turned pale.

d. Le métal s'est rougi sous l'effet de la chaleur.

(Zribi-Hertz 1987:45)

The metal SE reddened under the effect of the warmth.

d. [II] lance une campagne montrant une jeune femme qui fume (trop)

tranquillement une cigarette, et à mesure de ses bouffées, sa peau se vieillit.

[he] launches a spot showing a young girl which is smoking a cigarette (too)

quietly, and with her puffs, her skin SE is aging.

Note that (14a-b) below show that the COS in $(13 a, b)$ is conceived as internally caused, since the verb+object combinations at hand do not transitivize. Nevertheless, the reflexive construal is totally acceptable in (13a-b), in contradiction with Claim 1 according to which se is used only for externally caused eventualities. By contrast, verbs of class B (e.g. s'amaigrir) have the AC-reading with se even with animate subjects (cp. 15 with $12 \mathrm{~b}$ ).

(14) a. *L'annonce de la victoire a rougi ses yeux.

The announcement of victory has reddened her eyes.

b. $\quad *$ Le producteur/stockage a vieilli le vin.

The producer/storing aged the wine.

Marie s'est amaigrie/??a amaigri.

(class B)

Marie SE is a-thinned/ø a-thinned.

A third problem for Claim 1 is that when the COS is conceived as externally caused according to the transitivization test, the $\varnothing$-AC of class $\mathrm{C}$ verbs is not systematically ungrammatical. For us, (8a) repeated below is perfect without se, and we find examples such as in (16) in corpora (again also accepted by our informants).
a.'
Il vit le mouchoir
rougir.

(pace Labelle 1992)

He saw the handkerchief $\varnothing$ redden.

a. [Son] cou a rougi au soleil.

Her neck $\varnothing$ reddened from the sun.

b. La peinture a noirci sous l'effet de la fumée des bougies.

The painting $\varnothing$ blackened under the effect of the candles' smoke.

A fourth problem for Claim 1 is that it contradicts the intuition conveyed by traditional grammars. Indeed, se-ACs are often said there to underline some responsibility of the subject for the COS to evolve (authors cited by Zribi-Hertz 1987:24). For instance, Vendryes 1948 claims that the reflexive clitic marks "la participation du sujet au procès" [the participation of the subject to the process], Grevisse 1969 suggests that $s e$ "met en relief l'activité personnelle du sujet", marks "un intérêt particulier de ce sujet dans l'action" [it focuses on the personal activity of the subject, marks a particular interest of this subject in this action], and Gougenheim assumes that se indicates that the subject "a contribué pour une part si 
minime soit-elle à l'action subie" [contributed even for a very minimal part to the endured action]. We backed up this intuition with a small experiment: 8 native speakers were asked to pick among the se-AC and $\varnothing$-AC of two verbs of class $\mathrm{C}$ the one which attributes more responsibility/agentivity to the (inanimate) subject. They all chose the se-AC in (17) and (18):

$$
\begin{aligned}
& \text { a. La rose a flétri. } \\
& \quad \text { The rose } \varnothing \text { faded. }
\end{aligned}
$$

(18) a. Le métal a rouillé.

The metal $\varnothing$ rusted.
b. La rose s'est flétrie.
The rose $S E$ faded.
b. Le métal s'est rouillé.
The metal SE rusted.

Note that these verbs can, in principle, be used transitively with a causer subject (so they are really anticausatives, not unergatives or pure unaccusatives), cf. (19).
a. Le gel a flétri les rameaux.
The frost faded the branches.
b. L'humidité a rouillé le métal.
The humidity rusted the metal.

A fifth problem for Labelle's line of argumentation in favour of Claim 1 concerns the examples (20) below, which, so goes the claim, suggest an internal/external causation contrast. For our informants however, the examples in (20) do not show any tangible difference in grammaticality.
a. Après l'extraction du nerf, les dents noircissent.
b. $\quad *$ Après l'extraction du nerf, les dents se noircissent. (good for us) After the extraction of the nerve, the teeth blacken.
c. Les murs près de la cheminée se noircissent.
d. ?Les murs près de la cheminée noircissent.
(good for us) The walls near the chimney are becoming black.

Other examples where Labelle 1992 identifies a meaning difference involve a contrast between bare verbs and a prefixed counterpart, cf. (21)-(22). We think that the slight meaning differences in these examples result from meaning differences between grandir/agrandir (the latter restricted to spatial/physical contexts), not from the class A vs. class B membership of the two verbs.
(21) a. Les entreprises grandissent.
b. Les entreprises s'agrandissent.
(22) a. La plage d'ombre a grandi.
b. La plage d'ombre s'est agrandie.
The shadow spot got bigger.

Our interim conclusions are as follows. First, the claim that $s e$-ACs are externally caused while $\varnothing$-ACs are internally caused cannot be upheld as it meets numerous counterexamples, cf. also Zribi-Hertz 1987. Second, anticausatives of class C (optional verbs) have to be realized as $\varnothing$-ACs if their DP is +human. However, this holds even if the verb expresses an externally caused event. Third, for verbs of Class $\mathrm{C}$, speakers ascribe more responsibility for the COS to the DP in the se-variant than in the $\varnothing$-variant. 


\subsection{An alternative explanation: A pragmatic account}

As just emphasized, there remain two robust differences between se-ACs and $\varnothing$-ACs, but they emerge only with ACs of class C: (i) Human DPs are out in se-ACs (difference A); (ii) If forced to choose the structure that ascribes more responsibility to the DP, speakers prefer the se-variant over the $\varnothing$-variant (difference B). We account for these both differences through a competition-driven pragmatic explanation.

\subsubsection{Explaining difference $A$}

Our account of difference A rests on three observations. The first one is that reflexively marked strings are ambiguous between a number of semantic argument structures. They can correspond to (i) a semantically reflexive verb, (ii) an anticausative and (iii) a reflexive passive or generic middle. Concentrating on the first two readings, a reflexively marked string could origin either from structure III or structure IV below:

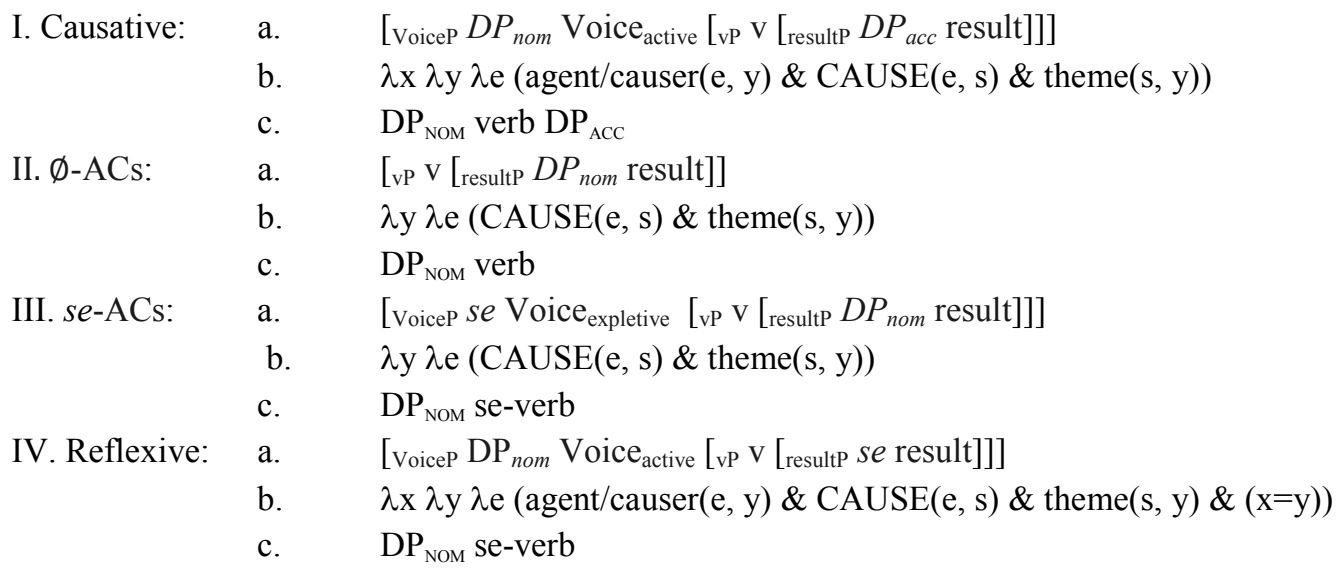

In sum, the structures III and IV differ syntactically and semantically, but do not differ differ in their morpho-phonology (i.e. surface string).

The second relevant observation is that for some interpretations, the morphological form is fixed by the grammar (i.e. lexicon or syntax), whereas for others there is optionality:

a) Reflexive semantics have to be expressed with the syntax in IV.

b) Anticausative verbs of class A are lexically restricted to enter structure II.

c) Anticausative verbs of class B are lexically restricted to enter structure III.

d) Anticausatives of class $\mathrm{C}$ are compatible with both structure II and structure III.

With verbs of class A, an ambiguity between a reflexive and an anticausative interpretation will never arise. On the other hand, anticausative verbs of class B are at the surface ambiguous as their morphophonology could also convey the reflexive structure in IV. So here, grammar does not make disambiguation available. Finally, for anticausative verbs of class C, Structure II does not lead to ambiguity (only anticausative), while Structure III leads to an ambiguity of the surface string (anticausative or reflexive). In that latter case, grammar makes disambiguation available. 
The third relevant observation is that semantically reflexive construals are overwhelmingly found with human agents acting on themselves but not with non-human causers acting on themselves. ${ }^{1}$ Anticausatives, on the other hand, typically express a change of state and are overwhelmingly found with non-human DPs. As a consequence, Structure III leads to a salient ambiguity or alternative parse only if the DP is thuman.

Alltogether, these three observations allow us to account for difference A with the help of the Gricean Maxim Avoid ambiguity (if possible)! (Grice 1989). The reasoning goes as follows: if the full DP has agent properties (+human), the [Ø-ACs] is preferred over the [se-ACs] to avoid that the hearer arrives wrongly at a reflexive interpretation. If we do not find a similar effect with verbs of class $\mathrm{B}$, it is because those lexically enforce the presence of se: the speaker has therefore no choice between several structures. Note that related competition effects have been observed to hold between semantically reflexive construals and se-passives. For instance, Zribi-Hertz 1982:361 observes that the se-passive is acceptable with an animate DP only if the verb involved is not a so-called 'naturally reflexive verb'. Obviously, the logic behind these facts is of the same kind here, namely to avoid that the hearer arrives at a pragmatically favored but wrong interpretation.

\subsubsection{Explaining difference $B$}

Remember difference B between marked and unmarked anticausatives: if forced to choose the structure that ascribes more responsibility to the DP, speakers prefer the $s e$-variant over the $\varnothing$-variant. We can easily explain it as follows:

(i) Responsible arguments are agents or causers.

(ii) Agents/Causers map to the external argument position.

(iii) se-ACs are formally ambiguous between an anticausative and a reflexive structure.

(iv) $\varnothing$-ACs are not ambiguous

(v) only reflexive structures involve an external argument position which could host a responsible DP (agent/causers)

That is, only the se-ACs string is compatible with an alternative derivation where the DP could be an external argument, i.e. responsible.

\subsection{Further arguments for claim 1}

In section 2.3, we exposed a first set of arguments in favour of Claim 1, showed the empirical problems they raise and provided an alternative pragmatic account of the remaining facts. The following subsections deal with additional arguments in favour of Claim 1 (external vs. internal causation) provided by Labelle 1992 and DL, and show that they are not decisive either.

\subsubsection{Mettre à}

As a further argument for Claim 1, Labelle 1992 and DL present the fact that se-ACs (both from class B and C) are excluded from the construction mettre $x \grave{a} P$, cf. (24), an observation originally due to ZribiHertz 1987.

(23) Le sucre (se) caramélise.

The sugar (SE) is caramelizing. 
(24) Il a mis le sucre à (*se) caraméliser.

He has put the sugar to (SE) caramelize.

According to DL, this construction describes "the fact of creating the appropriate conditions for an autonomous [i.e. internally caused] process to take place". Given Claim 1, se-ACs are predicted to be excluded from the structure, because they denote externally caused (i.e. non-autonomous) events. However, this argumentation misses several empirical facts, which make the above semantic characterization of mettre $\grave{a}$ unfeasible. First, transitive verbs are sometimes embeddable under mettre $\grave{a}$, cf. (25a) and (26). The COS expressed by these transitive verbs is not conceivable as autonomous: laver does not form an anticausative, cf. (25b); raccourcir does, but the COS in (26a) is clearly conceived as external caused given the context. The acceptability of (25a) and (26a) therefore raise a first difficulty for the hypothesis that mettre à requires the embedded verb to express an autonomous COS.
a. Il a mis le pantalon à laver.
He put the trousers to wash.
b. *Le pantalon a lavé.
The trousers washed.
a. Il a mis le pantalon à raccourcir chez le tailleur. He put the trousers to shorten at the tailor.
b. Le pantalon a raccourci.
The trousers shortened.

Second, clearly internally caused COS verbs are sometimes not acceptable under mettre à, cf. (27a). (Note that one can imagine 'appropriate conditions for flowers to blossom'). Third, verbs of class B can enter the construction if the reflexive is dropped, cf. (28).
a. $\quad$ *Il a mis les roses à fleurir/ le pain à pourrir.
He put the roses to blossom/ the bread to rotten.
b. Il a mis la pâte à lever.
He put the dough to rise.
a. $\quad 11$ a mis le fichier à convertir.
He put the file to convert.
b. $\quad$ Le fichier *(se) convertit.
The file (SE) is converting.

In conclusion, while DL are right to claim that there are clearly lexical-semantic restrictions on the verbs that can be embedded under 'mettre à', these are neither captured by the distinction between internal vs. external causation nor by the morphology an AC takes.

\subsubsection{The distribution of de-PPs}

The second additional argument that Labelle 1992 and DL offer in favour of Claim 1 rests on the distribution of $d e$-PPs with anticausatives. Zribi-Hertz 1987 observes after Boons et al. 1976 that in presence of a certain de-PP, verbs of class C can sometimes only form se-ACs, cf. (29a-b). Labelle 1992 compares (29) where the $\varnothing$-version of optional verbs reject a $d e$-PP with cases where it accepts it, cf. (30). 
(29) a. Le ballon gonfle (*de gaz carbonique).

The ball $\varnothing$ is inflating (with carbon dioxide).

b. Le ballon se gonfle (de gaz carbonique).

The ball SE is inflating (with carbon dioxide).

Marie a rougi de honte.

Marie Ø blushed from shame.

Labelle sees the paradigm illustrated in (29)-(30) as a further confirmation of Claim 1. Her reasoning can roughly be reconstructed as follows:

(i) $\varnothing$-ACs denote autonomous processes (Claim 1)

(ii) Given Claim 1, the subject of $\varnothing$-ACs must be conceived as the main Actor (the Responsible entity) of the event $e$.

(iii) Distinction between Causing entity and Responsible entity:

the $d e$-PP is acceptable in $\varnothing$-ACs as soon as the entity it denotes is a mere Cause of $e$, but does not have the responsibility in $e$.

(iv) the $d e$-PP expresses a mere Cause in (30), but the responsible entity in (29a), hence the contrast.

This line of argumentation raises two difficulties. First, Labelle offers no clear independent ground for the distinction between causing and responsible entities. Second, the $\varnothing$-form of gonfler intransitive is acceptable with avec-PPs, whose argument arguably plays the very same role in the event as the problematic $d e$-PP in (29a), cf. (31)-(33), all taken from the internet.

(31) Il a gonflé avec de l'Hélium!

It $\varnothing$ inflated with helium.

(32) Le [volcan] Tharsis a gonflé avec du magma au cours des premiers milliards d'années de la planète.

The volcano Tharsis $\varnothing$ inflated with magma in the first billions of years of the planet.

L'oeil [...] a gonflé avec du sang qui est entré dedans.

The eye $\varnothing$ inflated with blood which entered in it.

So whatever is the constraint explaining the ban on de-PPs with some Ø-ACs like gonfler in (29a), it cannot be due to the fact that the denoted entity is conceived as responsible of the event, since the licensed avec-PP has arguably the same thematic role.

Note that enfler, another translation of inflate, does not take a de-PP, even with the reflexive morphology, cf. (34). This suggests that the constraint on the $d e$-PP is not purely of a conceptual nature.

$$
\begin{aligned}
& \text { Le ballon (s')enfle (*de gaz carbonique). } \\
& \text { The balloon (SE) inflated with carbon dioxide. }
\end{aligned}
$$

We are unsure whether the (non-)availability of $d e$-phrases is totally idiosyncratic (verb specific) or whether there are generalizations to be made. In any case, the explanation building on the contrast 'responsible entity' vs. 'causer' does not seem to accurately account for the empirical picture. 


\section{Alleged meaning difference 2: Aspectual differences}

As mentioned in the introduction, $\varnothing$-ACs and se-ACs have also been claimed to show aspectual differences. According to Labelle 1992 and DL, $\varnothing$-ACs focus on the process, whereas se-ACs focus on the final state of the COS (what we called claim 2 above). LD explain these alleged aspectual contrasts through a difference in the syntactic structure of each form. Very briefly, in the $\varnothing$-AC, the two verbal projections $\mathrm{V}$ and $\mathrm{V}$ are supposed to be present; $\mathrm{v}$ introduces an activity subevent, and $\mathrm{V}$ a change leading to a state. The verbal root merges with $\mathrm{v}$, hence the focus on the process. On the other hand, in the se$\mathrm{AC}$, only $\mathrm{V}$ is present and thus no process subevent is introduced. The verbal root therefore has to merge with $\mathrm{V}$, hence the focus on the result state.

One immediate problem for an analysis along this line is that there is no indication/empirical argument that the two ACs differ in event complexity (e.g. the number of readings with adverbs like 'again' seems to be identical). In fact, traditional event decomposition tests, like the interpretation of negation or the French construals corresponding to almost and again, force to conclude that the two constructions have the same event decomposition (we illustrate this for class C, but the point holds for class A and class B, too):

(35) a. La branche a failli casser.

The branch almost broke.

(i) counterfactual reading (nothing happened to the branch)

(ii) scalar reading (something happened to the branch but it was not broken at the end)

b. La branche a failli se casser.

The branch almost SE broke.

(i) counterfactual reading

(ii) scalar reading

(36) a. La soupe a re-refroidi.

The soup has again cooled down.

(i) repetitive reading (two cooling down events)

(ii) restitutive reading (two states of being cool)

b. La soupe s'est re-refroidie.

(i) repetitive reading

(ii) restitutive reading

Moreover, as we show in detail through sections 3.1 to 3.4 below, the empirical arguments in favour of Claim 2 are not convincing (pace Legendre \& Smolensky 2009, who also argue for an aspectual difference between marked and unmarked $\mathrm{AC}$, but only within class $\mathrm{C}$ verbs).

\subsection{The distribution of in and for adverbials}

According to Labelle 1992:398, for-phrases are acceptable only with $\varnothing$-ACs, because they denote a process and no state, cf. (37a). Since se-ACs focus on the result state, they are more natural with inadverbials, cf. (37b).

a. Le ciment a/*?s'est durci pendant 3 heures. (judgments of Labelle 1992:398) 
The cement $\varnothing /$ SE hardened for 3 hours.

b. Le ciment a/s'est durci en 3 heures. (ibid.)

The cement $\varnothing / \mathrm{SE}$ hardened in 3 hours.

According to our judgements however, the empirical claim illustrated in (37a) does not hold. For us (37a) is acceptable with both ACs, and further examples where the reflexive variant of class $\mathrm{C}$ verbs combines with for-adverbials can be found in corpora and are accepted by our informants, cf. e.g. (38a-e).

a. Le temps s'est radouci pendant 3 ou 4 jours.

The weather softened for 3 or 4 days.

b. J'ai eu le ventre qui s'est durci pendant quelques secondes mais rien de douloureux.

My belly SE hardened for some seconds but nothing painful.

c. un carnet d' adresses qui s'est épaissi pendant trente-cinq ans est précieux. An address book that SE thickened for thirty five years is very useful.

d. L'afflux d'émigrants s'est ralenti pendant quarante ans.

The immigrants flood SE got slower for forty years.

e. Tel petit in-18, in-12, ou même in-32, qui s'est noirci pendant vingt années à l'étalage d'un bouquiniste, sur le quai Voltaire ou sur le pont de la Cité, renferme dans ses maigres flancs trois ou quatre pages échappées aux recherches des plus infatigables bibliophiles.

Such small in-18, in-12, or even in-32, which SE blackened for twenty years in the window of a second-hand bookseller, encloses in its thin sides three or four pages having escaped the hunting of the most tireless book lovers.

Besides this first difficulty, we note that the alleged contrast in $(37 \mathrm{a}, \mathrm{b})$ does also not manifest itself in class A or class B. Indeed, we find $\varnothing$-ACs of class A licensing $i n$-adverbials as well as se-ACs of class B licensing for-adverbials, cf. (39).

a

Le T-Shirt a séché en deux minutes.

The T-Shirt $\varnothing$ dried in two minutes.

b. Son état s'est amélioré pendant plusieurs mois, les médecins s'occupant de lui parlant de véritables miracles.

His state SE got better for several months, the doctors taking care of him were speaking of true miracles.

The second argument Labelle 1992 offers in favour of Claim 2 is that verbs of class A, which normally enter the unmarked construction only, sometimes can form se-ACs (that is shift to class C), but only in perfective sentences and in presence of $i n$-adverbials, so that the focus is put on the result. Her hypothesis is that in that case, the perfective morphology and the in-adverbial have a licensing role on the use of the se-construction, cf. (40) (all judgments taken from Labelle 1992). This prima facie supports the view that se-ACs focus on the result state.

(40) a. Le poulet s'est cuit en très exactement 30 minutes. (Zribi-Hertz 1987:344)

The chicken cooked in exactly 30 minutes.

b. $\quad *$ Le poulet se cuisait.

(OK as passive) 
c. $\quad *$ Le poulet s'est cuit pendant trois heures.

According to our intuition however, cuire is not shifted to class $\mathrm{C}$ in (40) --- with the reflexive, it strongly tends to be interpreted as a passive. One piece of evidence for this is provided by the interpretation of tout seul 'by itself'. Under the most natural interpretation of (41b), tout seul gets with se cuire the reading it gets with se-passives:

a. La branche s'est cassée toute seule.

The branch SE broke by itself.

Reading (i): no entity caused the breaking of the branch (anticausative)

Reading (ii): it was very easy to break the branch (passive)

b. Le poulet s'est cuit tout seul.

The chicken SE cooked by itself.

\#Reading (i): no entity caused the cooking of the chicken (anticausative)

Reading (ii): it was very easy to cook the chicken (passive)

For us, (40b) and (40c) are in fact acceptable once the passive interpretation is made salient in the context. We think that if this passive interpretation is more accessible out of the blue with a en-adverbial (cf. (40a) than with a for-adverbial (cf. (40c), it is because the telic interpretation triggered by enadverbials is very easily associated with an intentional interpretation. This in turns makes the interpretation of the implicit argument that goes with the passive reading more salient.

As a further argument for our reanalysis of Labelle's data, we observe that causer-PPs are acceptable with the $\varnothing$-version but are quite degraded under the se-marking; this follows if se-passives have an agentivity restriction on the implicit argument.
a. L'oeuf a cuit sous l'effet de la chaleur.
The egg cooked under the effect of the warmth.
b. ??L'oeuf s'est cuit sous l'effet de la chaleur.
The egg cooked under the effect of the warmth
(cf. also Kupferman 2009)

\subsection{The argument of muer}

The second set of arguments in favour of Claim 2 offered by Labelle 1992 and DL bears on the verb muer, which, so the claim, forms a se-AC only in presence of a resultative en-PP (43a), while it forms a $\varnothing$-AC only without it, cf. (43b). DL argue that since the se-AC focuses on a result state, an explicit description of this state is needed in (43a), and since the $\varnothing$-AC focuses on the process, the state is deemphasized. This is supposed to make an explicit state description impossible.
a. L'oiseau s'est mué *(en un monstre à trois têtes).
The bird SE changed (in a monster with three heads).
b. L'oiseau a mué (*en un monstre à trois têtes).
The bird Ø moulted (in a monster with three heads).

Again, we do not think that the paradigm of muer supports Claim 2. To begin with, we do not agree with the judgment in (43b); cf. also the following examples (44), all found on the internet. 
(44) a. Jadis réputé pour sa formule café et dessert, le [restaurant] Lézard a mué en un hybride Formely known for his cafe and dessert formula, he restaurant Lézard $\varnothing$ changed in a hybrid.

b. Il a mué en un bon groupe de rock. It $\varnothing$ changed in a good rockband.

c. La voix a mué en un croassement démoniaque.

The voice $\varnothing$ changed in a demonic cawing.

We propose the following alternative analysis for the remaining accurate data (43a). On one hand, muer with en-PP (muer en) is an AC of class C (or alternatively of class A for speakers rejecting (43b) with the $e n$-PP and examples in (44)). On the other hand, muer without en-PP is an unergative verb (cf. also ZribiHertz 1987). We see three arguments in favour of the hypothesis that the intransitive muer is lexically ambiguous (between an anticausative and an unergative construal). First, only muer en can be transitivized, cf. (45). Second, only muer en allows an adjectival passive, cf. (46). Third, muer with or without $e n$-PP is lexicalized differently in other languages (e.g. transform into vs. molt (*into)) and the same meaning difference holds in French examples in (45a, b).

a. $\quad$ Pierre a mué sa voix *(en un croassement démoniaque).

Pierre changed his voice in a demonic cawing.

b. $\quad$ *Le virus a mué l'oiseau.

(Zribi-Hertz 1987:40)

The virus moulted the bird.

c. Le virus a mué l'oiseau en un monstre à trois têtes. (ibid.)

The virus transformed the bird in a monster with three heads.

(46) a. * L'oiseau est mué.

(Zribi-Hertz 1987:42)

The bird is moulted.

b. L'oiseau est mué en un monstre à trois têtes.

The bird is transformed in a monster with three heads

\subsection{The argument of the restriction on metaphorical uses}

A third kind of arguments in favour of Claim 2 rests on the restriction on the metaphorical uses of anticausatives. Lagane 1967 and Ruwet 1972 observed that sometimes, with verbs of class C, the se-AC is blocked when the verb is used in a metaphorical way, cf. (47)-(49).

a. La sauce s'épaissit.

The sauce is thickening up.

(48) a. La plante (se) tasse.

The plant is packing down.

(49) a. La sauce (se) réduit.

The sauce is reducing. b. $\quad$ La nuit*(s')épaissit.

The night is deepening.

b. Le problème * (se) tasse. The problem is packing down.

b. $\quad$ Le problème $*(\mathrm{se})$ réduit. The problem is reducing.

Labelle 1992:393 proposes to see in these facts another confirmation of Claim 2: the metaphorical transfer does not operate on the process, but only on the state. That is, under the figurative reading, the 
abstract entity is not "presented as undergoing a physical process of [...] thickening up; they are rather presented as being in a state which $[\ldots]$ can be described as $[\ldots]$ more thick".

Apart from the fact that it is not completely clear why metaphorical uses should involve a focus on the result state rather than on the process, we do not think that there is a true generalization here. First, we observe that with other verbs, the metaphorical use enters the unmarked construction, cf. (50), again taken from corpora. Second, in some cases, the zero-AC is marked on the literal use, rather than on the metaphorical one, cf. (51).

a. Le progrès ralentit.

The progress is getting slower.

b. Lorsqu'ils sont entourés de béni oui-oui, leur esprit ramollit.

When they are surrounded by yes-men, their spirit gets softer

c. A la fin l'argent a tari et le commerce a fini.

At the end money dried up and business stopped.

(51) a. ?Mon livre épaissit.

My book is thickening.

b. ?Mes fichiers épaississent.

My files are thickening.

\section{Conclusions}

In this paper, we contested previous analyses according to which $\varnothing$-ACs and se-ACs systematically differ in meaning, on the basis of new data, mostly found in corpora. We argued that French $\varnothing$-ACs and se-ACs do not show systematic meaning differences wrt focusing on subevents and internal vs. external causation. This supports our claim that the presence vs. absence of se should not be associated with fundamentally different syntactic structures predicting such semantic differences. Finally, we showed that the true remaining meaning differences accurately noticed by Labelle 1992 and DL are either restricted to class $\mathrm{C}$ verbs and follow from pragmatic considerations, or are idiosyncratic to individual verbs.

\section{Acknowledgements}

We would like to thank two anonymous reviewers and Steffen Heidinger for valuable feedback. Martin and Schäfer's research was supported by grants to the projects B5 and B6 within the Collaborative Research Center 732 at the University of Stuttgart. The authors' names are purely alphabetical.

\section{References}

Alexiadou, A., Anagnostopoulou, E. and F. Schäfer. 2006. The properties of anticausatives crosslinguistically. In M. Frascarelli (ed.), Phases of Interpretation, Berlin: Mouton de Gruyter, $187-211$.

Bernard, G. 1971. La transitivité en français contemporain. Thesis, Université de Rennes.

Boons, J.-P., A. Guillet and C. Leclère. 1976. La Structure des phrases simples en français, I: constructions intransitives, Genève: Droz. 
Burston, J. 1979. The pronominal verb construction in French: an argument against the fortuitous homonymy hypothesis. Lingua 48, 147-176.

Chierchia, G. 2004. A semantics for unaccusatives and its syntactic consequences. In A. Alexiadou, et al. (eds.), The unaccusativity puzzle: explorations of the syntax-lexicon interface, 22-59. Oxford: OUP.

Doron, E. 2003. Agency and Voice: the semantics of the Semitic templates. Natural language semantics, 11(1), 1-67.

Doron, E. \& M. Labelle. 2011. An ergative analysis of French valency alternation, in Herschensohn, J. (ed), Romance Linguistics 2010: Selected Papers from the 40th Linguistic Symposium on Romance Languages (LSRL). Amsterdam: Benjamins. 137-154.

Gougenheim. G. 1939. Système grammatical de la langue française, Paris: Bibliothèque du français moderne.

Grevisse, M. 1969. Le bon usage, Gembloux: Duculot.

Grice, P. 1989. Studies in the Way of Words. Cambridge, Massachusetts: Harvard University Press.

Horvath , J \& T. Siloni. 2011. Anticausatives: Against Reflexivization. 2011. Lingua 121, 2176-2186.

Horvath, J. \& T. Siloni. 2013. Anticausatives have no Cause(r): A Rejoinder to Beavers and KoontzGarboden. To appear. Lingua. 131, 217-230

Koontz-Garboden, A. 2009. Anticausativization. Natural Language and Linguistic Theory 27:77-138.

Kupferman, L. 2009. Evénéments et anti-causativité. Des topoï à la théorie des stéréotypes en passant par la polyphonie et l'argumentation dans la langue. Hommages à Jean-Claude Anscombre. Presses universitaires de Savoie, 397-408.

Labelle, M. 1992. Change of state and valency. Journal of Linguistics 28, 375-414.

Labelle, M. and E. Doron. 2010. Anticausative derivations (and other valency alternations) in French. Probus 22-2, 303-316.

Lagane, R. 1967. Les verbes symétriques: économie morpho-syntaxique et différentiation sémantique. Cahiers de lexicologie, X-1.

Legendre, G. \& P. Smolsensky 2009. French Inchoatives and the Unaccusativity Hypothesis. In Gerdts et al. (eds.), Hypothesis A/Hypothesis B: Linguistic Explorations in Honor of David M. Perlmutter. MIT Press.

Levin, B. \& M. Rappaport Hovav. 1995. Unaccusativity: At the Syntax-Lexical Semantics Interface, Cambridge: MIT Press.

Rothemberg, M. 1974. Les verbes à la fois transitifs et intransitifs en français contemporain, La Haye: Mouton.

Ruwet, N. 1972. Théorie syntaxique et syntaxe du français. Paris: Le Seuil.

Schäfer, F. 2008. The syntax of (anti-)causatives. External arguments in change-of-state contexts. Amsterdam: Benjamins.

Schäfer, F. \& M. Vivanco. 2013. Reflexively marked anticausatives are not semantically reflexive. Talk at Going Romance, University of Amsterdam.

Smith, C. S. 1970. Jespersen's 'Move and Change' Class and Causative Verbs in English. M. A. Jazayery, E. C. Polomé and W. Winter (eds.), Linguistic and Literary Studies in Honor of Archibald A. Hill. Vol. 2: Descriptive Linguistics. The Hague: Mouton de Gruyter, 101-109. 
Vendryes, J. 1948. Une catégorie verbale: le mode de participation du sujet. Bulletin de la société linguistique, XLIV-1, 128.

Zribi-Hertz, A. 1982. La construction 'se-moyen' du français et son statut dans le triangle moyen-passifréfléchi. Lingvisticae Investigationes, 6/2, 345-401.

Zribi-Hertz, A. 1987. La réflexivité ergative en français moderne. Le Français moderne, 55 (1), 23-52.

\footnotetext{
${ }^{1}$ Non-human DPs can be put in a semantically reflexive construal, but then the reflexive relation must be marked via the addition of an intensifier. So in order e.g. to translate the branch broke itself, the intensifier is needed in French, cf.. la branche s'est cassée elle-même. Without intensifier (e.g. la branche s'est cassée), only the anticausative reading is available, see Schäfer \& Vivanco 2013. In fact, these authors claim that in anticausative structures, the intensifier is even not allowed, so that non-human DPs with verbs of class C never lead to an ambiguity. As a consequence, the claim by Koontz-Garboden 2009 (who follows a proposal by Chierchia 2004) that anticausatives marked with a SE-reflexive are semantically reflexive although their nominative DP is non-human cannot be upheld. This hypothesis has been convincingly refuted by Horvath \& Siloni 2011, 2013 and Schäfer \& Vivanco 2013.
} 